\title{
Importance of Beef Cattle Farming Model and Appropriate Benefits for Small-Scale Farmers in Nakhon Sawan Province, Thailand
}

\author{
Thunwa Wiyabot ${ }^{1} \&$ Piyalap Manakit ${ }^{2}$ \\ ${ }^{1}$ Department of Agricultural Technology, Faculty of Agricultural Technology and Industrial Technology, Nakhon \\ Sawan Rajabhat University, Thailand \\ ${ }^{2}$ Department of Industrial Technology, Faculty of Agricultural Technology and Industrial Technology, Nakhon \\ Sawan Rajabhat University, Thailand \\ Correspondence: Thunwa Wiyabot, Department of Agricultural Technology, Faculty of Agricultural Technology \\ and Industrial Technology, Nakhon Sawan Rajabhat University, Thailand. E-mail: thunwa.thun8@gmail.com; \\ Thunwa.w@nsru.ac.th
}

Received: April 27, 2021

Accepted: May 26, $2021 \quad$ Online Published: June 15, 2021

doi:10.5539/jas.v13n7p101

URL: https://doi.org/10.5539/jas.v13n7p101

\begin{abstract}
The objective of this study was to investigate the feasibility and reasonable production costs for small cattle farmers in Nakhon Sawan Province of Thailand. Small-scale beef cattle are naturally reared by farmers without planning. Studying the primary data of beef cattle farming models and comparing the economic return costs of each form of beef cattle farming among smallholder farmers in Nakhon Sawan Province of Thailand shows that the yields are not worthwhile. By applying the specific method to $25 \%$ of the area of all farms in Nakhon Sawan Province and comparing the descriptive statistical yields, the results showed that two types of cattle with 4 characteristics predominate. The first is rearing pregnant mother cows for sale and buying mother cows. The second category is feeder cattle, release cattle and fattening cattle. A study of the costs and economic compensation of suitable small-scale beef cattle farmers in Nakhon Sawan Province of Thailand found that cattle farms should raise cattle because the yield from farming is valued and because of the economic returns and the time spent. The payback for this form is faster than other forms of investment.
\end{abstract}

Keywords: beef farmers, farming style, production returns, Thailand

\section{Introduction}

Raising beef is one profession of Thai farmers. Cows were formerly raised for use in fields when there was no need to use the fields or the cows are older, and farmers then sold the cows as meat for consumption. Since small-scale beef cattle farmers are naturally reared and without planning, the yields are not worthwhile. Especially in the Nakhon Sawan Province of Thailand (as shown in Figure 1), the farmers' primary income is from the cultivation of rice fields, and the average family income from animal husbandry is 188,941 baht/year (Office of Agricultural Economics, 2017; Dadi et al., 2014). The past preferred secondary occupation of beef cattle was as laborers. However, currently, farmers use machinery and labor-saving devices instead of animal labor, which make beef cattle less important for farmers; therefore, farmers raise fewer cows. As the world population increases, the demand for beef dishes also increases; thus, the beef production for consumption is insufficient to meet the population's needs, especially in Thailand. Therefore, beef cattle must be imported from foreign countries by importing live cattle from neighboring countries (Department of Livestock Development, 2017a; Khamkwan et al., 2012). The importation of live cattle may cause an epidemic of animal diseases and animal diseases transmitted to people due to latent infections in imported animals. In the past, without control and strictness from those involved, especially foreign animal quarantine stations, most farmers in Thailand raised cattle, and tiny farmers in the Nakhon Sawan Province of Thailand had low raising standards. Cattle returns create a bundle. However, considering cattle production and a career as additional income, initial investments in permanent cow stalls were made because of the view that fattening cows would be a good career enhancement. In general, farmers are raising herds that graze on the grass that grows in the wilderness or public fields or grow the grass to address the food shortage. Research on the farming conditions and production management of such farmers found that a lack of standards and essential farm management affect meat quality and consumer safety (Kannika et al., 2012; Suphawadee, 2016). These problems arose from the lack of knowledge and understanding 
that farm management has a direct impact on beef cattle farmers, and another important thing is that beef rearing is still a supplementary occupation or a low-cost endeavor for a small-scale farmer (Suporn \& Chalermsak, 2007; Saithong \& Boonyanuwat, 2011; Larson \& Fuller, 2014). Government agencies from the government sector must provide knowledge. Regarding the management of beef cattle farms, farmers have to adjust their production to suit the farm's profitability. They are increasing production levels, increasing income for farmers in Thailand, and raising beef cattle (Ekachai, 2011; Naramon et al., 2007).

Therefore, this study focused on comparing the farming patterns and suitable substitutes of small farmers in Nakhon Sawan Province. The study seeks to provide information on choosing a production model, including obstacles in the farm management of beef cattle farmers, that is suitable for the resource and production management of smallholder farmers in Nakhon Sawan Province and as a way to reduce costs.
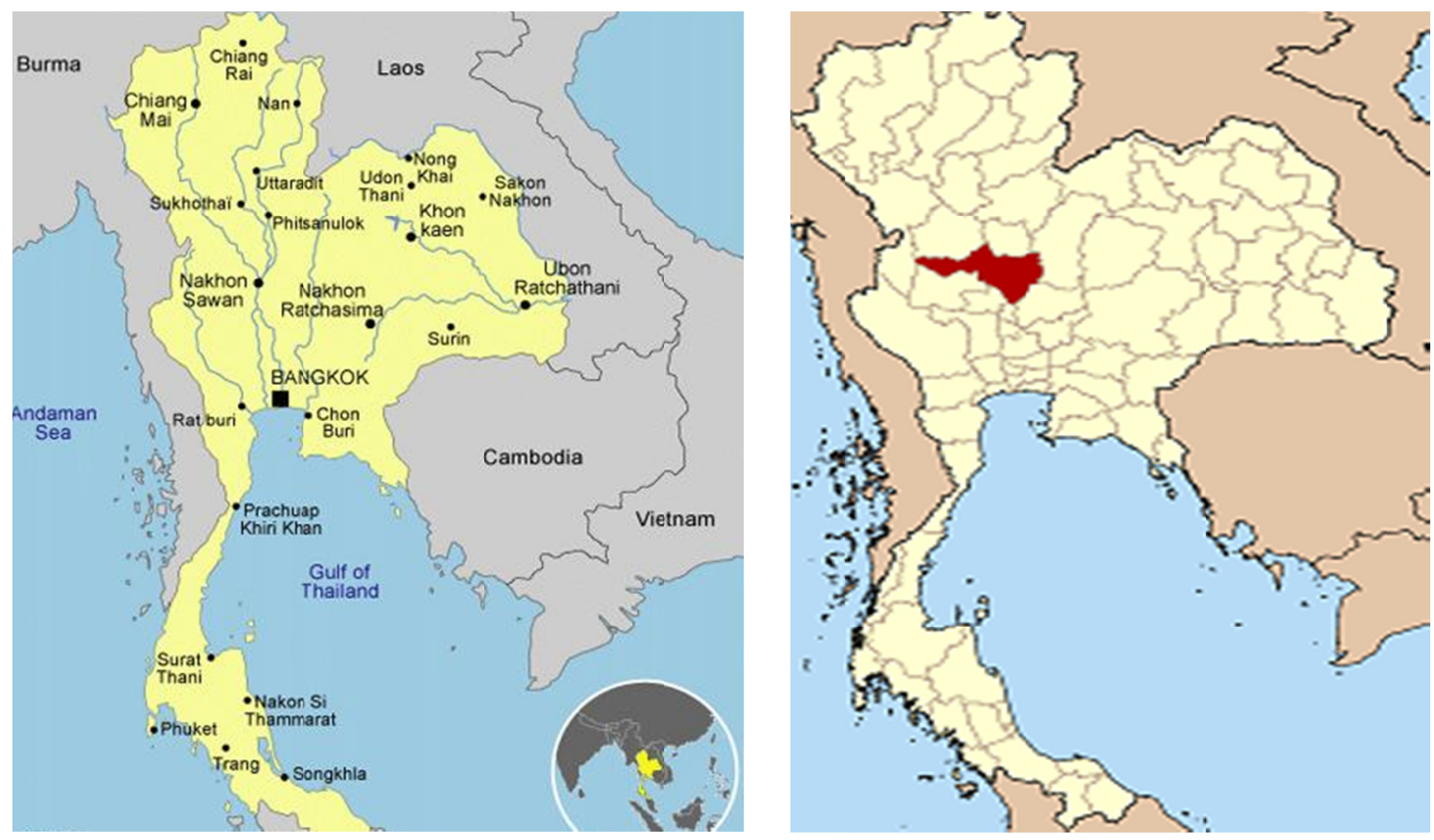

Figure 1. Shows the location of Nakhon Sawan province of Thailand

\section{Methods}

\subsection{Study Area}

This study is on the patterns of small-scale beef cattle farming in Nakhon Sawan Province of Thailand. This research conducts survey research. The questionnaire method was applied to farmers who responded to a specific interview using purposive sampling. Small-scale farmers accounted for $25 \%$ or 30 of 125 farms in Nakhon Sawan Province of Thailand (Theerawut, 2000).

\subsection{Data Collection}

The data were sampled without using nonprobability sampling accidentally or convenience sampling. Factors related to costs that cause costs to be unclear and complicated to identify are latent variables. These cannot be used to calculate labor costs. In addition, public utilities such as electricity, water and other utilities cannot determine how much it costs to raise a cow. As farmers spend these costs together in their everyday daily lives, the data collection is divided into two parts:

(1) The primary data were obtained from interviews seeking to collect data from farmers. Confounders and intervening variables were identified with a causal diagram, and confounders were included in the models.

(2) The secondary data were data obtained from the collection of academic papers, research reports, books, and other related documents for analysis and summarization of the investigation and primary data to support farming. This study uses the purposive sampling method and records the farmers' data. Information was gathered from 
small-scale farmers (interviewed farms) to study the general details and engage in farm research using the research findings.

The data on the production costs of beef cattle production are divided into 1) variable costs consisting of labor costs, variety, roughage, minerals, breed, medical supplies and medicine, water and electricity, inorganic and service costs, opportunity costs, investment, etc. and 2) fixed costs including house depreciation and cattle depreciation. The average values are calculated by the proposed cost and return analysis equations. Overhead costs are fixed costs and adjusted to variable costs. The hidden costs are the production and service costs. Especially for small farmers raising cattle, the costs were found to be less than average and the same. The discount rate is the value that we use to increase or decrease the value of money as the money changes hands. We do not have information on the discount rate.

Then, the data are used to calculate the costs and production returns such as feed costs, feed costs per gain, production index, economic loss, sellable head return, return on investment, net profits per head and net profits per kg. Net Profit is the profit obtained from calculating the total income minus costs and expenses, including selling fees. Net present value is the difference between the present value of the total net expenditure and net cash inflow. This research uses the Net Present Value (NPV) to analyze the feasibility of a project.

\subsection{Data analysis}

Primarily, the associations between management and each reproductive performance measure were tested using the linear regression model (PROC GLM) procedure (SAS, 2008). Confounders and intervening variables were identified with a causal diagram, and confounders were included in the models. Second, this research compiled and analyzed the average values and compared the production costs and product returns. This research studies the descriptive statistical data consisting of the percentages and means of the investment, purchase, distribution, production costs and production returns of each farm (Boonchom, 2002) to compare the quantity of each form of farming to compare and evaluate the differences. Confounders were kept as fixed effects in the models. A two-way interaction was tested and observed in the models if significant $(\mathrm{p}<0.05)$ using SAS version 9.2 (SAS, 2008).

\section{Results}

This study of the rearing patterns and production returns of small beef cattle farmers in Nakhon Sawan Province of Thailand explored the beef cattle farms in Nakhon Sawan Province of Thailand using beef farm survey results and collecting farmer data on the format and costs of beef cattle farming in Nakhon Sawan Province of Thailand. The experimental results are as follows. The farming patterns of small-scale farmers in Nakhon Sawan Province of Thailand were studied. The results on the beef cattle raising of smallholder farmers in Nakhon Sawan Province of Thailand found that there are two forms of beef cattle farming with 4 characteristics as follows.

The first form of raising for sale includes two types: pregnant cows and buying breeders. Pregnant cows are purchased from the cattle and buffalo market. The cows bought have a baby in the belly or the mother has a baby with them. When the baby in the womb is born, the calf will be raised until its age reaches the selling age. Then, the cow is brought back to the cattle and buffalo market to be sold or is sold to merchants who buy it from its home to sell at the cattle and buffalo market, as shown in Figure 2-buying a mother to raise and finding a breeder to raise by herself until having children. When the baby is born and raised until it reaches the age range that it can be sold, it is brought back to the cattle and buffalo market be sold or sold to merchants who come to its home to buy it to sell at the cattle and buffalo market, as shown in Figure 3.

The second type of feed cow is for sale. There are two types of farming: the release of the released cow in a field and beef cattle imprisoned as feed cows. A released cow is a purchased cow aged 18 months with a weight of 230 kilograms and above with details that follows. The cows are then fattened in the field until they reach 550 kilograms and up. Then, the cows are brought back to the cattle and buffalo market to be sold or merchants come to their home to buy the cows to raise. Figure 4, image 5 show that the beef castle imprisoned for purchase and sale are feed cows that are bought as calves that are aged 18 months and weigh 230 kilograms or more that are supplemented with concentrated and coarse feeds until they reach up to 550 kilograms or more. Merchants may send the cattle abroad according to their weight. 


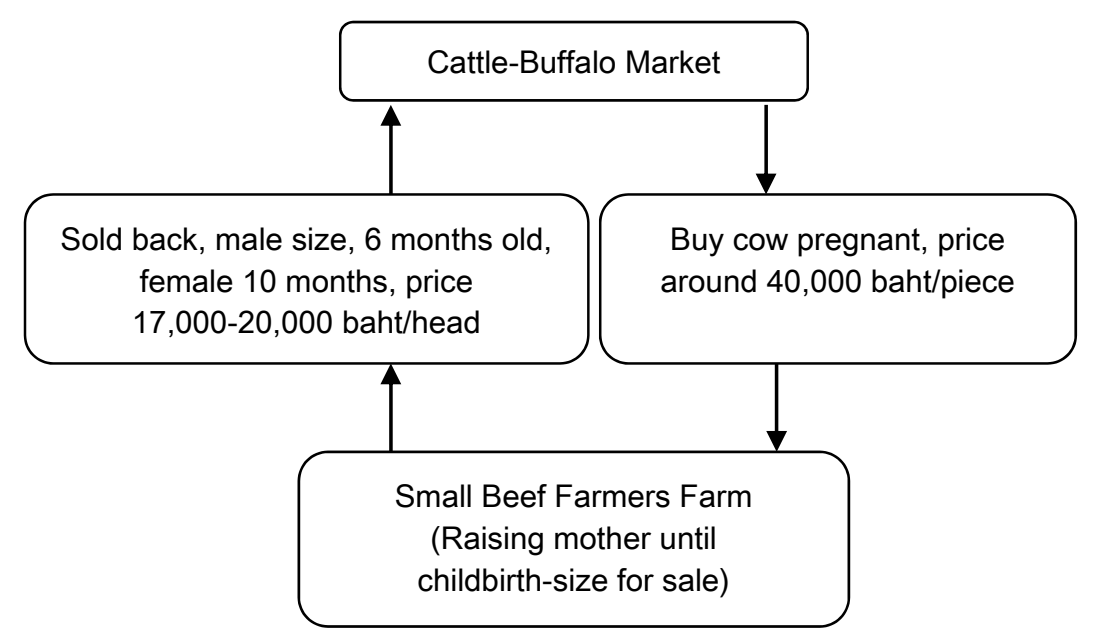

Figure 2. Shows raising for sale style buy cow pregnant (trading prices as of year 2019)

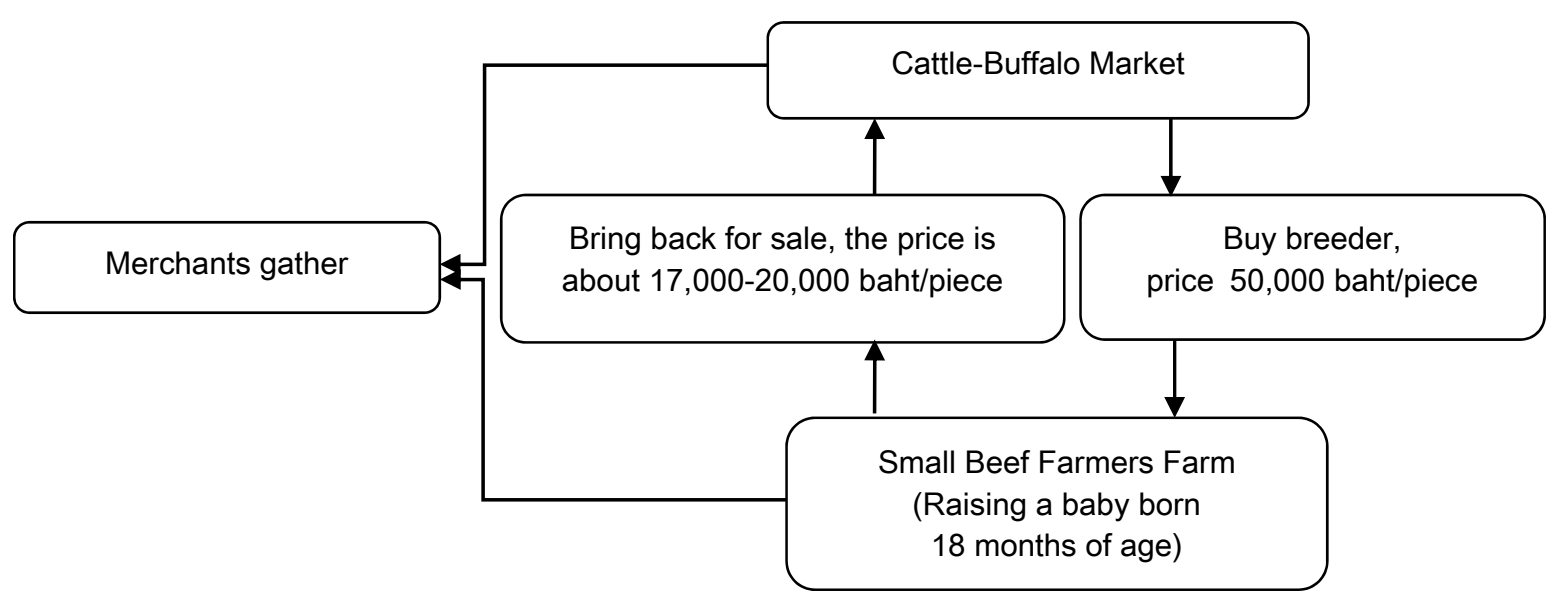

Figure 3. Shows raising for sale style buy breeder (trading prices as of year 2019)

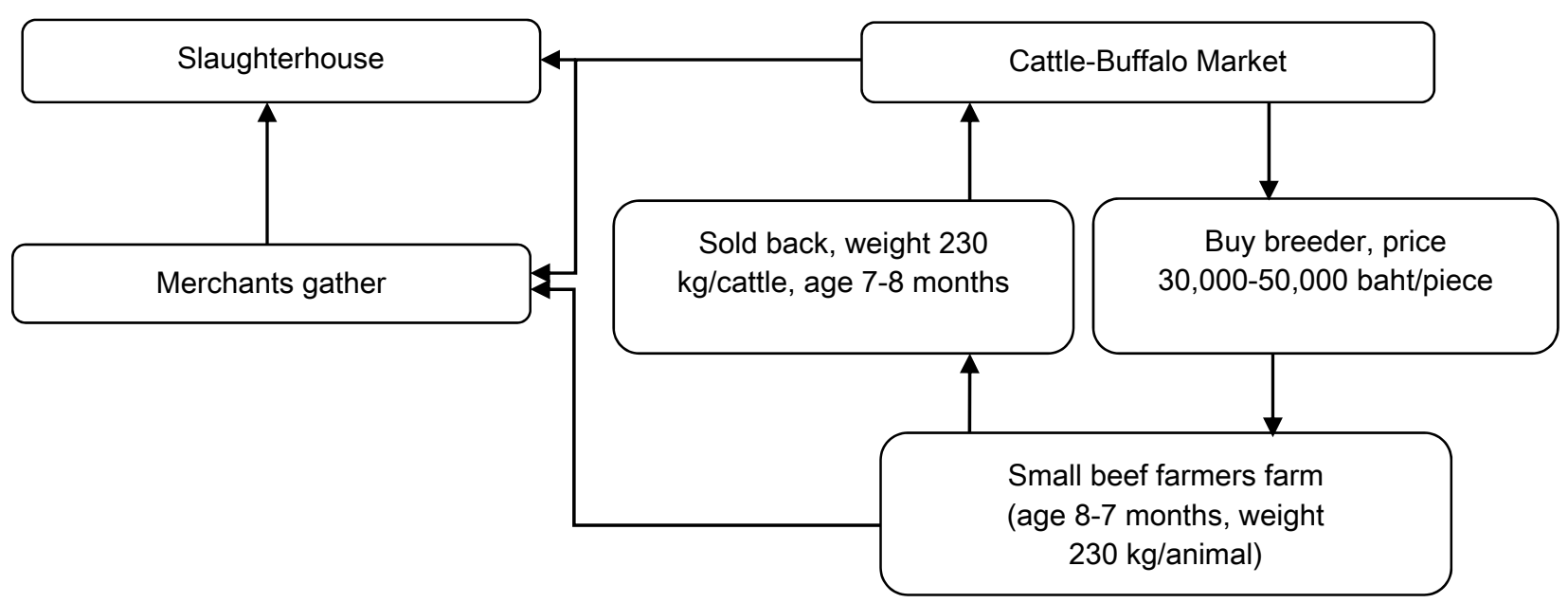

Figure 4. Shows feed cow style released cow (trading prices as of year 2019) 


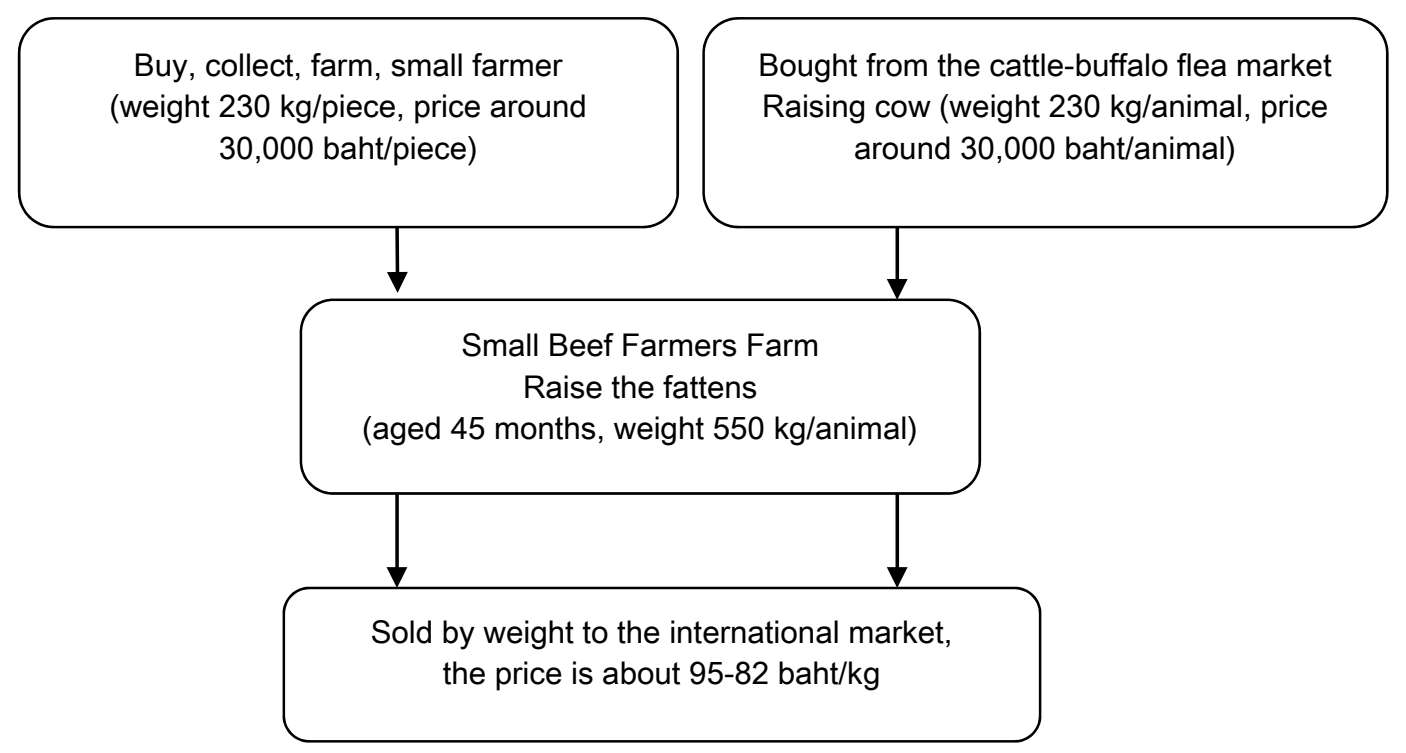

Figure 5. Shows feed cow style Khun ko imprisoned (trading prices as of year 2019)

There are two styles with four characteristics, which are the following. Type 1 is those cows that are raised for sale, including buying pregnant cows and buying breeder breeds. Type 2 feed cows are released cows and imprisoned feed cow cattle. The study of the rising patterns and production returns of small beef cattle farmers in the Nakhon Sawan Province of Thailand found that most farmers are males aged 51-60 years and raise beef cattle later from the parent model. Farming involves the release of imprisoned cow and beef cattle. Farmers will start selling cows at the age of 1 and a half to 2 years or at a weight of 230-250 kilograms.

\subsection{Study on Farming Costs and Production Compensation of Small Beef Cattle Farmers in Nakhon Sawan Province of Thailand}

The study of the costs and compensation in beef production can be classified according to the cultural pattern found by the small agricultural group in Nakhon Sawan Province of Thailand. There are two types with four characteristics, which are 1 type raised for sale and pregnant cows. The second type is to buy breeders, feed cows, released cows and imprisoned beef cattle. It has been found that the rent costs of pregnant cows is 6.25 baht/head/year. Breeder cows accounted for $83 \mathrm{baht} / \mathrm{head} / \mathrm{year}$ of land rent. Raising feed cow style released cows has its own costs. Similar to the cow feed style, imprisoned beef cattle are classified by the housing construction costs of small-scale agricultural groups in Nakhon Sawan Province of Thailand. The results found that the costs of constructing a building for pregnant cows is $40,000 \mathrm{baht} /$ house, the housing costs for breeders is 50,000 baht/house, the construction costs to house cow feed type released cows is 50,000 baht/house and the building costs for a imprisoned feed Khun ko cows is 100,000 baht/house. Beef breeders from the small agricultural group in Nakhon Sawan Province of Thailand stated that the costs of pregnant beef cows are 50,000 baht/head per breeder. The beef cattle cost 50,000 baht/parent, the released feed cattle cost 30,000 baht/cow, and the imprisoned beef cattle cost 32,000 baht/cow, as classified by the thick/coarse feed of small-scale group agriculture in Nakhon Sawan Province of Thailand. The purchase price of pregnant cows was $65 \mathrm{baht} /$ piece/year, and the purchase price of breeders was 38 baht/piece/year. The feed cow type was beef cattle. Imprisoned cattle cost $18 \mathrm{baht} / \mathrm{animal} / \mathrm{year}$ for feed costs according to the small-scale agricultural group in Nakhon Sawan Province of Thailand, and the purchased pregnant cows self-graze. In addition, regarding the released feed cows, imprisoned Khun ko cows cost to $0.39 \mathrm{baht} / \mathrm{head} / \mathrm{year}$ for feed, and the costs for cut grass and other drugs for imprisoned Khun ko cows was 4 baht/head/day. In addition, regarding supplementary food, the small agricultural group in Nakhon Sawan Province of Thailand stated that pregnant cow supplements and other drugs were 213 baht/body/year. Other drugs and buying breeder supplements were 62.5 baht/piece/year.

Other drugs and supplements for feed cows and released cows cost 50 baht/piece/year. Other drugs and supplements for feed cows and imprisoned beef cattle cost $190 \mathrm{baht} /$ piece/year. Regarding straw, the small agricultural group in the Nakhon Sawan Provide in Thailand stated that the straw costs of pregnant cows is 318 baht/animal/year. The straw bales for breeders cost $104 \mathrm{baht} / \mathrm{animal} / \mathrm{year}$. The straw costs for released cows were $400 \mathrm{baht} /$ person/year. Regarding the labor of the small-scale agricultural group in Nakhon Sawan Province of 
Thailand, the group stated that the labor costs for pregnant cows is $37 \mathrm{baht} / \mathrm{piece} / \mathrm{month}$. The labor costs for breeders were calculated assuming that the breeders were self-raised. The labor costs for released feed cows were $4.66 \mathrm{baht} / \mathrm{head} / \mathrm{month}$. The labor costs for imprisoned beef cattle are $66 \mathrm{baht} / \mathrm{piece} / \mathrm{month}$. Regarding the electricity/water costs of small agricultural groups in Nakhon Sawan Province of Thailand, the electricity/water costs for pregnant cows are $250 \mathrm{baht} /$ year. The electricity purchase/water costs were $500 \mathrm{baht} / \mathrm{month}$. The electricity/water costs for released feed cows were 500 baht/month. The electricity and water costs for imprisoned beef cattle feed cows were $500 \mathrm{baht} / \mathrm{month}$. Next are the transportation costs of the Kasai Krai group in Nakhon Sawan Province of Thailand. The transportation costs for imprisoned Khun ko feed cows were 200 baht/cow. The corn spray costs of small agricultural groups in Nakhon Sawan Province of Thailand are also assessed. The aerosol costs of pregnant cows were 93 baht/piece/year, and the corn dust mist costs of imprisoned feed cows were $8 \mathrm{baht} / \mathrm{piece} / \mathrm{month}$.

The total costs of pregnant cows (with a baby in the belly) were 90,982 baht/unit. The total costs of buying breeders and breeders for mixing by themselves were 150,787 baht/unit. The total costs for fattening cows released in a field were 80,954 baht/unit. The total costs for imprisoned beef cattle were 132,986 baht/unit - which are according to the prices and data for small beef cattle production in Nakhon Sawan Province of Thailand. The breeder raised for sale and imprisoned Khun ko feed cows had significantly higher production costs. The other farming styles were statistically significant $(\mathrm{p}<0.05)$, as shown in Table 1 .

Comparing the production costs and returns of the beef cattle farming model in Nakhon Sawan Province of Thailand found that the feed costs per gain of pregnant cows are 3.95 baht, the feed cost are 158 baht, the production index is 52.75 , the economic loss equals $-2,472$, the sellable head return equals 20,000 , the return on investment equals 20,154 , the net profits per head equal $-30,982$, and the net profits per kg equal -63 . For the breeders, the feed cost per gain are 3.55, the feed costs are 142 baht, the production index equals 59.72 , the economic loss equals -995 , the sellable head return equals 20,000 , the return on investment equals 301 , the net profits per head equal $-8,0787$, and the net profits per kg equal -179 . For feed cows, the feed costs per gain equal 0.65 , the feed costs (FCs) equal 126 baht, the production index equals 56.23 , the economic loss equals -912 , the sellable head return equals 50,850 , the return on investment equals 419 , the net profits per head equal 17,864 and the net profits per kg equal 66. Comparing the production returns (production cycle) of the cattle farming model in Nakhon Sawan Provide of Thailand, feed cows had a higher production index, economic loss, sellable head return, return on investment, net profits per head and net profits per $\mathrm{kg}$. The other patterns were statistically significantly different $(\mathrm{p}<0.05)$, as shown in Table 2 .

Comparing the costs and returns for 15 years of production of beef cattle in Nakhon Sawan Province of Thailand showed that the costs of pregnant cows were 90,000 baht/piece, and the raw material and transportation costs were 14,730 baht. The total costs of pregnant cows are 104,730 baht, the revenues of pregnant cows are 125,000 baht, and the net profits of pregnant cows are 20,270 baht. For breeders, the investment costs are 90,000 baht/piece, the raw material and transportation costs are 11,805 baht, the total costs of breeders are 101,805 baht, the revenues of breeders are 120,000 baht, and the net profits of breeders are 18,195 baht. For released cows, the investment costs are 450,000 baht, the raw material and transportation costs are 14,310 baht, the total costs of released cows are 464,310 baht, the revenues of released cows are 600,000 baht, and the net profits of released cows are equal to 135,690 baht. For imprisoned Khun ko cows, the investment costs are 945,000 baht, the raw material and transportation costs are 179,160 baht, the total costs are equal to $1,124,160$ baht, the revenues are equivalent to $1,525,500$ baht, and the net profits of are equal to 401,340 baht. The comparison of the production costs and returns for beef cattle farming in Nakhon Sawan Province of Thailand for a period of 15 years shows that fattening cattle should be farmed because the yields from cattle raising and trade and faster payback are statistically significantly different $(\mathrm{p}<0.05)$ from those of other forms, as shown in Table 3 . 
Table 1. Shows cost and data for small beef cattle production in Nakhon Sawan province of Thailand

\begin{tabular}{|c|c|c|c|c|}
\hline \multirow{3}{*}{ Item } & \multicolumn{4}{|c|}{ Farming Style } \\
\hline & \multicolumn{2}{|c|}{ Raising for sale } & \multicolumn{2}{|c|}{ Feed cow } \\
\hline & Cows pregnant & Buy breeder & Released cow & Khun ko imprisoned \\
\hline \multicolumn{5}{|l|}{ Fixed cost } \\
\hline 1. Land rental fee (baht/person/year) & $6.50 \pm 0.25$ & $85 \pm 0.21$ & Own land & Own land \\
\hline 2. Construction cost (baht) & $40,000 \pm 7.25$ & $50,000 \pm 7.12$ & $50,000 \pm 6.23$ & $100,000 \pm 5.25$ \\
\hline \multicolumn{5}{|l|}{ Variable cost } \\
\hline Beef breed values (baht/head) & $50,000 \pm 6.21$ & $50,000 \pm 5.44$ & $30,000 \pm 4.63$ & $32,000 \pm 5.88$ \\
\hline 2. Meal cost of feed (baht/piece) & $65 \pm 0.75$ & $40 \pm 0.45$ & $\mathrm{~N} / \mathrm{A}$ & $1,050 \pm 0.77$ \\
\hline \multicolumn{5}{|l|}{ 3. Capital on grass plots } \\
\hline Fertilizer & $\mathrm{N} / \mathrm{A}$ & N/A & $\mathrm{N} / \mathrm{A}$ & N/A \\
\hline Seed cost & $\mathrm{N} / \mathrm{A}$ & $\mathrm{N} / \mathrm{A}$ & $\mathrm{N} / \mathrm{A}$ & $\mathrm{N} / \mathrm{A}$ \\
\hline Fuel cost for cutting grass (baht/person/year) & $\mathrm{N} / \mathrm{A}$ & $\mathrm{N} / \mathrm{A}$ & $\mathrm{N} / \mathrm{A}$ & $0.45 \pm 0.01$ \\
\hline Wage cutters (baht/b/day) & $\mathrm{N} / \mathrm{A}$ & N/A & $\mathrm{N} / \mathrm{A}$ & $5 \pm 0.02$ \\
\hline 4. Other drugs and supplements (baht/head/year) & $41.5 \pm 0.32$ & $62.5 \pm 0.25$ & $50 \pm 0.35$ & $120 \pm 0.25$ \\
\hline Straw cost (baht/piece/year) & N/A & $105 \pm 1.20$ & $400 \pm 1.44$ & $350 \pm 1.36$ \\
\hline Straw compression wage (baht/person/year) & $318 \pm 2.65$ & $\mathrm{~N} / \mathrm{A}$ & $\mathrm{N} / \mathrm{A}$ & $\mathrm{N} / \mathrm{A}$ \\
\hline 6. Labor cost (baht/piece/month) & $37 \pm 0.26$ & N/A & $4.66 \pm 0.63$ & $66 \pm 0.33$ \\
\hline 7. Electric bill/water bill (baht/month ( & $250 \pm 2.66$ & $500 \pm 3.56$ & $500 \pm 3.22$ & $500 \pm 2.36$ \\
\hline 8. Transportation costs (baht/person) & $\mathrm{N} / \mathrm{A}$ & $\mathrm{N} / \mathrm{A}$ & $\mathrm{N} / \mathrm{A}$ & $200 \pm 3.25$ \\
\hline 9. Corn fog cost (baht/month) & $95 \pm 0.45$ & N/A & $\mathrm{N} / \mathrm{A}$ & $85 \pm 0.55$ \\
\hline Total cost per head & $\mathbf{9 0 , 8 1 3} \pm 5.36^{\mathrm{a}}$ & $150,792 \pm 6.33^{b}$ & $\mathbf{8 0 , 9 5 5} \pm 5.21^{\mathrm{a}}$ & $133,525 \pm 6.54^{b}$ \\
\hline
\end{tabular}

Note. ${ }^{\text {ab }}$ Means in the same row without common letter are different at $\mathrm{P}<0.05 ; \pm$ is the value Standard Deviation (S.D.); N/A is the Not Applicable.

Table 2. Comparison of production returns (production cycle) beef cattle farming model in the Nakhon Sawan province of Thailand

\begin{tabular}{lllll}
\hline \multirow{2}{*}{ Item } & \multicolumn{2}{c}{ Farming style } & \multirow{2}{*}{ Average feed cow } & \multirow{2}{*}{ P-value } \\
\cline { 2 - 4 } & \multicolumn{1}{c}{ Cows pregnant } & Buy breeder & & 0.024 \\
Feed Cost (baht/kg) & $158 \pm 0.23^{\mathrm{a}}$ & $142 \pm 0.32^{\mathrm{a}}$ & $126 \pm 0.12^{\mathrm{b}}$ & 0.035 \\
Feed Cost per Gain (baht/head) & $3.95 \pm 0.11^{\mathrm{a}}$ & $3.55 \pm 0.13^{\mathrm{a}}$ & $0.65 \pm 0.23^{\mathrm{b}}$ & 0.045 \\
Production Index & $52.75 \pm 0.59^{\mathrm{b}}$ & $59.72 \pm 0.66^{\mathrm{a}}$ & $56.23 \pm 0.54^{\mathrm{a}}$ & 0.032 \\
Economic Loss (baht/head) & $-2,472 \pm 2.35^{\mathrm{b}}$ & $-995 \pm 2.33^{\mathrm{a}}$ & $-912 \pm 2.22^{\mathrm{a}}$ & 0.022 \\
Salable Head Return (baht/head) & $20,000 \pm 3.68^{\mathrm{a}}$ & $20,000 \pm 4.56^{\mathrm{a}}$ & $50,850 \pm 3.98^{\mathrm{b}}$ & 0.011 \\
Return of Investment (\%) & $20.15 \pm 0.23^{\mathrm{b}}$ & $38.1 \pm 0.55^{\mathrm{a}}$ & $41.9 \pm 0.33^{\mathrm{a}}$ & 0.025 \\
Net Profits per Head (baht/head) & $-30,982 \pm 2.36^{\mathrm{b}}$ & $-80,787 \pm 2.65^{\mathrm{c}}$ & $17,864 \pm 2.44^{\mathrm{a}}$ & 0.037 \\
Net Profits per Kg (baht/kg) & $-63 \pm 0.14^{\mathrm{b}}$ & $-179 \pm 0.12^{\mathrm{c}}$ & $66 \pm 0.18^{\mathrm{a}}$ & \\
\hline
\end{tabular}

Note. ${ }^{\text {abc }}$ Means in the same row without common letter are different at $\mathrm{P}<0.05 ; \pm$ is the value Standard Deviation (S.D.). 
Table 3. Comparison of production costs and returns (15 years) of beef cattle farming in Nakhon Sawan province of Thailand

\begin{tabular}{|c|c|c|c|c|c|}
\hline \multirow{2}{*}{ Item } & \multicolumn{2}{|c|}{ Raising for sale } & \multicolumn{2}{|c|}{ Feed cow } & \multirow{2}{*}{ P-value } \\
\hline & Cows pregnant & Buy breeder & Released cow & Khun ko imprisoned & \\
\hline Investment cost (baht/head ( & $90,000 \pm 5.33^{c}$ & $90,000 \pm 4.53^{\mathrm{c}}$ & $450,000 \pm 4.36^{b}$ & $945,000 \pm 5.66^{\mathrm{a}}$ & 0.045 \\
\hline Cost of raw materials and transportation (baht/head ( & $14,730 \pm 2.35^{\mathrm{b}}$ & $11,805 \pm 2.44^{b}$ & $14,310 \pm 1.36^{\mathrm{b}}$ & $179,160 \pm 2.00^{\mathrm{a}}$ & 0.015 \\
\hline Total cost (baht/head ( & $104,730 \pm 8.47^{c}$ & $101,805 \pm 7.48^{\mathrm{c}}$ & $464,310 \pm 6.89^{b}$ & $1,124,160 \pm 8.36^{\mathrm{a}}$ & 0.035 \\
\hline Benefit (baht/head ( & $125,000 \pm 6.39^{\mathrm{c}}$ & $120,000 \pm 6.58^{\mathrm{c}}$ & $600,000 \pm 6.88^{b}$ & $1,525,500 \pm 6.55^{\mathrm{a}}$ & 0.040 \\
\hline Net benefit (baht/head ( & $20,270 \pm 5.36^{\mathrm{c}}$ & $18,195 \pm 4.54^{\mathrm{c}}$ & $135,690 \pm 8.87^{b}$ & $401,340 \pm 8.69^{\mathrm{a}}$ & 0.025 \\
\hline
\end{tabular}

Note. ${ }^{\mathrm{ab}}$ Means in the same row without common letter are different at $\mathrm{P}<0.05$; \pm is the value Standard Deviation (S.D.). The price of beef cattle at the end of the year 2019, the purchase price of the beef cattle is $31,500 \mathrm{baht} / \mathrm{head}$, the price of the selling beef at the farm is 92 baht/kilogram in Nakhon Sawan province of Thailand.

\section{Discussion}

This study assesses the importance of the beef cattle farming model and appropriate benefits for small-scale farmers in Nakhon Sawan Province following Atchara (1995). The results found that farmers who raise most of the released cow types sold their cows when they were aged one year and no more than two years. This was followed by male cattle aged two years and no more than three years. The cows that were sold weighed 201-300 kilograms. Napharporn et al. (2017) reported that medium-sized beef cattle farmers in the province had 20 to 40 cattle; in addition, $78.3 \%$ of the farmers were male, with an average age of 53.5 years. Most of them had primary education and an average of 5 household members. The average farmer held 14.3 acres with an average agricultural income from the farming sector of 110,192.03 baht/household/year. In addition, the average income from the sale of beef cattle was 45,829.34 baht/household. Most farmers have 15-30 years of experience in beef cattle farming. Most of the farmers (71.65\%) have loans. Most sources of loans are from the Bank for Agriculture and Agricultural Cooperatives, which circulates money for farming and investing in beef cattle. Similar to Surawat and Charunee (2019), most of the farmers (70.28\%) are male. Furthermore, $79.42 \%$ of the farmers were married. In addition, $70.28 \%$ of the family members in the house work in raising beef cattle. The share of farmers that grazed cows along the road reached 52.57 percent, with the majority of 78.3 percent being males with an average age of 53.5 years and direct farming as the main occupation and raising beef as a secondary occupation (Napharporn et al., 2017; Thanaporn et al., 2018). For released cows, there are limited natural grass resources. Farmers lack the area for raising cows and lack water resources during the dry season. The data for choosing the suitable beef production model and selecting the right beef production model are lacking. The resource and production management seeking to reduce the problems and obstacles in farm management for farmers interested in beef farming have further compared the production models used in farmers' decisions (Napharporn et al., 2017). Wiyabot (2015) reports that beef cattle farming has two forms: beef cattle and pregnant cows as a low-cost feed. However, there is a product obtained from the investment. It takes only a year to produce the products. However, it takes 3-4 generations of raising cattle for the profits to cover the initial costs, and the buying breeders form of beef cattle farming is a low-cost and time-consuming cattle production method. Surawat and Charunee (2019) reported that most of the released cow models are cow farmers with an average beef production costs of $13,500.25$ baht/household. In addition, the average income from selling beef is $45,829.34 \mathrm{baht} / \mathrm{household}$, with average profits of 2,335 baht/body. Napharporn et al. (2017) found that the cattle raising system was $85.63 \%$ of the total, and $14.37 \%$ of the herds of imprisoned Khun ko beef cattle were American Brahma crossbred cattle, followed by cattle breeders, Charles breeders and native beef cattle. In addition, Surawat and Charunee (2019) said that released cow beef, which is raising cows to produce cows, has lower production costs because most of them are costs. Noncash production, such as farmers' labor and rough food in public areas, fields, farms, and gardens, does not cost money for food, resulting in higher returns than for imprisoned Khun ko beef.

Cattle raising in an open cow style and the characteristics of raising farmers will drive cattle for public use in the local buffalo market. The most popular breeds of released cows among farmers are native beef cattle (Napharporn et al., 2017). Sompong and Pairote (2009) study the local cow production system in Chiang Mai Province. Farmers graze their herds on grasses in public areas. Chaiyawan and Tharnglingsak (2008) study the released cow system in Songkhla Province. Most farmers let cows graze by eat grass, bought cows themselves, 
and bred the cows on their farms in flocks. Their purchases will be breeders or good-quality cows to wait for breeders in the future.

Another case is that farmers buy weaned cows to release their cows for sale to those who will continue to fatten them. Farmers' significant problems and obstacles to released cows are natural grass sources, and there is a limited area for raising herds (Surawat \& Charunee, 2019). However, the advantages of the cows are that the cows are kept for a shorter time than those of the herd version. In the cows, caged farmers can raise three generations of cows in 1 year. Caged cows provide better returns than cow herds. However, imprisoned beef cattle farming is expensive, requiring systematic farm management and allowing only a small number of farmers to sustainably feed (Napharporn et al., 2017; Surawat \& Charunee, 2019). Used to be abandoned farmers are increasingly turning to economic crops. Less public space due to an invasion of public space is causing farmers to raise more cattle to earn a living, and the household income of released cow farmers is 45,000-100,000 baht per year (Surawat \& Charunee, 2019). Released cow beef raises cows to produce children with lower production costs because most of the production costs are not cash, resulting in higher returns than for imprisoned Khun ko cows.

Imprisoned beef cattle farming is suitable for farmers with capital because most of the costs are the cattle breeds, concentrated feed and coarse feed, which are cash costs (Surawat \& Charunee, 2019; Napharporn et al., 2017). When farming imprisoned beef cattle, most farmers will buy cow breeds from the cattle and buffalo market, followed by buying from small-scale farmers in the nearby area. The most popular species of imprisoned Khun ko cattle are crossbred American Brahman cows. As for the images and faculty, it found that the Khun ko-type beef cattle farmers are farmers who bought beef from 1 to 2 years of age to feed concentrated feed for 4-5 months such that the sale weight of the cows was 300-400 kilograms or 400-500 kilograms. The cost of raising imprisoned Khun ko beef cattle showed that farmers buy cows between the ages of 1 year-2 years that weigh approximately 230-250 kilograms, and fattening will take approximately 4-5 months until the weight is 500 kilograms. There are farmers that buy cattle from farms and engage in released cow farming. Farmers will feed cows until they have calves and will raise calves for another one and a half years until two years until they are sold at market. The costs of raising caged cows is mostly the cattle breeds, concentrated feed and coarse feed, which are cash costs. The problems and obstacles in the production of imprisoned Khun ko beef are expensive food and inadequate forage (Napharporn et al., 2017).

The cost and return analysis for released cow beef production costs are primarily variable costs that are not cash, such as wages because farmers use household labor. The costs and compensation of beef production in the 15th year of each model showed the total production costs. The total costs of pregnant cows are $90,813 \mathrm{baht} / \mathrm{unit}$. The total costs of a breeder are 150,792 baht/unit. The total costs of released cows are $80,955 \mathrm{baht} / \mathrm{unit}$, and the total costs of imprisoned Khun ko cows are 133,525 baht/unit. The imprisoned Khun ko feed cows require high investment costs. The return on small beef cattle production in the 15th year showed that the imprisoned Khun ko feed cows were highly profitable and provided a quicker return on investment than other farming practices. In addition, rough food income comes from the sale of beef cattle. Beef cattle aged one year, one year and a half years, two years, and no more than three years resulted in production costs of 4,289, 4,383 and 9,300 baht each with profits of 3,711, 7,657 and 5,881. The returns over cash costs are 7,603 baht per 11,293 and 12,398 baht, respectively (Surawat \& Charunee, 2019).

Cattle raising using released cows has lower production costs because most of the costs are noncash production costs such as the labor costs of household farmers and food expenses. According to Wiyabot's (2015) study, the released feed cows using low-cost cattle require a period of fattening. The required weight at which farmers prefer to buy beef cows aged is achieved between 1.5-2 years after raising the cows for approximately 8-12 months. Therefore, the cows are sold after one year and no more than two years. The cattle weight at that point is 201-300 kilograms. Merchants on the farm buy beef cows mostly through distribution channels. Some farmers sell cows at the local buffalo market. Farmers find that the cattle sold from raising in their herd have low production costs because most of the production costs do not require cash. For example, coarse food in public areas, fields, and gardens does not cost money for food but has a long farming period. Regarding the costs of a released cow, the labor costs are 6,000-9,000 baht per month, the costs of cattle breeding are 83.33-416.67 baht per month, the treatment costs are 101-500 baht per month and the opportunity costs of investment are 42-210 baht per month with total costs of 6,226.33-10,126.67 baht per month. Regarding the returns on beef cattle farming, farmers have income in the range of 8,333.75-12,500 baht per month, and the profits from beef cattle farming are 2,107.42-2,373.33 baht per month, according to Mekdaeng et al. (2011). Most merchants buy cattle from a farmer's farm to sell the chartered form, with only some weighing methods. Most of the production costs are cattle costs. In addition the concentrated food costs were more than $80 \%$ of the total price. The value of cows 
will depend on the breed, age and size of the cows purchased. Raising cows is expensive, but the duration of raising cows is less for some cows releasing herds form the raising costs of herds (Wiyabot, 2015). Regarding the raising costs for an imprisoned Khun ko beef farmer, farmers bought 1-2-year-old beef cattle and feed them concentrated feed for 4-5 months before they are sold. The weights of the cattle that are sold are mainly 300-400 kilograms. The costs of raising a herd of beef cattle are formed by farmers who buy beef cows between the ages of 1.5-2 years to fatten for approximately 8-12 months; therefore, they sell the cows in 1 year and not more than two years.

The weights of the cattle that are sold are mainly 201-300 kilograms. Regarding the distribution channel, most broilers come with merchants to buy at the farm. Some farmers sell the cows at the local buffalo market (Napharporn et al., 2017) after feeding the cows using the imprisoned Khun ko style with high investment costs. However, high profits and a short period of fattening can fatten food and leave time for work or personal business (Wiyabot, 2015). Yaemkong (2016) researched the production costs and compensation for the beef production of agriculture in Phitsanulok Province. The total production costs of fattening and raising cows for offspring are 36,082.86 $\pm 20,514.87$ and 18,898.45 $\pm 10,152.28$ baht per farmer, respectively. Fattening and raising cows for offspring had net returns of 14,642.14 $\pm 5,814.98$ and 9,541.78 $\pm 2,548.59$ baht per farmer, respectively, but released cows had a more extended breeding period than the young cows. Imprisoned Khun ko cattle farming is suitable for farmers with funds because most of the costs are the cattle breeds, feed concentrations and cattle feed. Coarse food is a cash cost, but the advantage of imprisoned Khun ko beef cattle is the shorter raising duration than for released cows (Surawat \& Charunee, 2019).

For 2019, after collecting data, the results found that the price of beef cattle in the country tended to decrease, causing some groups small farmers in Nakhon Sawan Province of Thailand to turn to raising beef cows. The production pattern of beef calves increases by 100 percent because calves of a hundred percent blood beef are more expensive than other forms, especially female calves.

\section{Conclusion}

In the study of the beef cattle farming patterns and reasonable production costs of small breeders in Nakhon Sawan Province of Thailand, the results showed two types of beef with 4 characteristics. The first type rearing pregnant cows and buying breeding stock. The second type is for the importance of the beef cattle farming model and appropriate benefits for small-scale farmers in Nakhon Sawan Province, Thailand. It was found that cattle should be farmed because the yields from cattle were high. In addition, it has faster payback than other forms of investment. This information can aid in choosing a production model suitable for the resource and production management of smallholder farmers in Nakhon Sawan Province and as a way to reduce costs, including obstacles in the farm management of beef cattle farmers.

\section{Acknowledgements}

The authors would like to thank Research and Development Institute and Animal Ethics Committee of Nakhon Sawan Rajabhat University Nakhon Sawan Province, Thailand to fund and allow this experiment.

\section{Reference}

Chaiyawan, W., \& Thaleesak, U. (2008). Production performance and characteristics of native cattle in southern Thailand under the system release farming in Songkhla Province. The Thailand Research Fund (TRF), Bangkok.

Chavalit, K., Kornthi, R., Matana, O., \& Thanathip, S. (2012). The cost of beef production of farmers who are members of the livestock raising cooperatives. Central Pone Yang Kham. Agricultural Science, 43, 79-88.

Dadi, L. S. H., Lee, S. S., Park, C., \& Kim, K. S. (2014). Inter-and intra-population genetic divergence of East Asian cattle population: Focusing on Korean cattle. Genes \& Genomics, 36, 261-265. https://doi.org/ 10.1007/s13258-013-0146-9

Department of Livestock Development. (2012). Livestock infrastructure information: Number of some livestock involved organization 2012. Ministry of Agriculture and Cooperative, Bangkok, Thailand.

Department of Livestock Development. (2015). Beef raising. Livestock Development for Export Project. Ministry of Agriculture and Cooperatives, Bangkok.

Department of Livestock Development. (2016). Annual research report. Food Division, Ministry of Agriculture and Cooperatives, Bangkok.

Department of Livestock Development. (2017a). Meat beef area, Area 6, Year 2018. Retrieved from http://www.dld.go.th 
Department of Livestock Development. (2017b). The amount of beef cattle in Nakhon Sawan province in 2015. Retrieved from http://www.dld.go.th

Ekachai, K. S. (2011). Animal husbandry certification standards. Bureau of Livestock Product System Development and Certification, Department of Livestock Development.

Kannikamek, D., Chittima, K., \& Atchara, P. (2012). Management of beef cows with caged and released herds Mueang District, Kanchanaburi Province (pp. 258-259). Graduate Research Research Conference, Sukhothai Thammathirat Open University 2nd time, September 4-5, 2012, Sukhothai Thammathirat Open University, Nonthaburi.

Khamkwan, D., Laepaijit, Y., Vitoonpong, E., \& Intaratham, W. (2012). Effect of inbreeding on growth traits in Esarn indigenous cattle. BAHGI e-Journal, 2, 15-27.

Lambertz, C., Chaikong, C., Maxa, J., Schlechtb, E., \& Gauly, M. (2012). Characteristics, socioeconomic benefits and household livelihoods of beef buffalo and beef cattle farming in Northeast Thailand. Journal of Agriculture and Rural Development in the Tropics and Subtropics, 113, 155-164.

Limsombunchai, V., \& Kao-ian, S. (2010). Selection of corn seed and returns for farmers at takfa, Nakonsawan province, corn and sorghum research project (p. 358). Kasetsart University, Bangkok.

Mekdaeng. K., Kantanamalakul, C., \& Ajchara, P. (2011). The production management of beef cattle in barns and free ranch at Muang district, Kanchanaburi province. The 2nd STOU Graduate Research Conference, Bangkok.

Napharporn, W., Theerarat, C., \& Wantanee, P. (2017). Beef cattle production and managament in barns and free ranch farming of farmers in borabue district Mahasarakham Province. Khon Kaen Agr. J., 45.

Narakon L, Chokmi, K., \& Natthaphon, C. (2007). Factors affecting the production of quality beef in the province Chiang Mai and Lamphu. Agriculture, 23, 235-239.

Nukreaw, R., \& Phunsoda, J. (2012). The study on situation of native beef cattle raising and satisfaction of farmers in Samutsongkram province (Reseach report). Nakhonpathom: Livestock Office.

Office of Agricultural Economics. (2017). Basic Agricultural economic information 2017 (Animal farmers' database). Office of Agricultural Economics, Ministry of Agriculture and Cooperatives Phetchaburi Provincial Livestock Office. Retrieved from http://pvlobr.dld.go.th/images/phocadownloadataanima/ data_beef_56.pdf

Phetchaburi Provincial Office. (2014). Basic economic restructuring to raise income levels for tourism and trade development. Retrieved from http://www.phetchaburi.go.th/data/pd/d7.pdf

Saithong, S., Chatchawan, T., \& Boonyanuwat, K. (2011). Thai indigenous cattle production provide a sustainable alternative for-benefit of smallscale farmers, healthy food, and the environment. BAHGI e-Journal, 1, 21-26. Retrieved from http://e-journal.dld.go.th/? $\mathrm{p}=680$

SAS Institute. (2008). SAS/STAT user's Guide v. 9. SAS Institule Inc., North Carolina.

Sompong, S., \& Pairote, S. (2009). Native cattle production system in Chiang Mai province. The Thailand Research Fund.

Supawadee, Y. (2016). Ton Tanu and compensation for beef production of farmers in Wat Bot District and Phrom Phiram District Phitsanulok Province. Journal of Agriculture, Faculty of Agriculture, Chiang Mai University, 32, 401-407.

Suphawadee, P. Y. (2016). Efficiency development of beef cattle production of small-scale farmers in chattrakan District, Phitsanulok Province. Rajabhat Journal of Sciences, Humanities and Social Sciences, 17, 3238.

Suporn, K., \& Chalermsak, R. (2007). The use of beef cattle production technology of farmers in Ron Phibun District. Nakhon Si Thammarat Province. Bureau of Animal Hygiene and Hygiene, 9(5), 9-14.

Surawat, C., \& Charunee, K. (2019). The production management, mactors influencing cost-related and profit return of grazing's beef cattle in Phetchaburi and Prachuap Khiri Khan. Eau Heritage Journal, 13, 201-208.

Teerawut, E. (2000). Research methods in behavioral education and social studies. Faculty of Education, Rajabhat Institute Ubon Ratchathani.

Thai Meteorological Department. (2013). The weather in Thailand. Retrieved from http://www.tmd.go.th/ en/region.php? RegionID=1 
Thanaporn, B., Niraporn, C., Chonlathee, K. \& Sanchai, J. (2018). Current situation and future prospects for beef production in Thailand-A review. Asian-Australas J Anim Sci, 31, 968-975. https://doi.org/10.5713/ ajas.18.0201

Waritthitham, A., Lambertz, C., Langholz, H. J., Wicke, M., \& Gauly, M. (2010). Assessment of beef production from Brahman $\times$ Thai native and Charolais $\times$ Thai native Crossbred bulls slaughtered at different weights. II: Meat quality. Meat Sci, 85, 196-200. https://doi.org/10.1016/j.meatsci.2009.12.025

Wiyabot, T. (2015). Beef farm academics. Faculty of Agricultural Technology, Nakhon Sawan Rajabhat University.

Yaemkong, T. (2016). Beef production cost and returns of farmers in Wat Bot and Phrom Phiram district, Phitsanulok Province. Journal of Agriculture, 32, 401-407.

Yodthong, T., \& Pairote, S. (2007). Beef cattle farming. Livestock Research and Development Group and Technology Transfer Department of Livestock Development, Ministry of Agriculture and Cooperatives.

\section{Copyrights}

Copyright for this article is retained by the author(s), with first publication rights granted to the journal.

This is an open-access article distributed under the terms and conditions of the Creative Commons Attribution license (http://creativecommons.org/licenses/by/4.0/). 